\title{
Pretreatment with Mycobacterium avium-derived lipids attenuates the response of murine macrophages to components of Mycobacterium tuberculosis
}

\author{
DAQING YANG, YUAN LIU, YIGUO CHEN, DELONG JIAO, XIAORUI HOU, LEI WANG and NING FU \\ Department of Immunology, School of Basic Medical Science, \\ Southern Medical University, Guangzhou, Guangdong 510515, P.R. China
}

Received December 27, 2011; Accepted February 8, 2012

DOI: $10.3892 / \mathrm{ijmm} .2012 .932$

\begin{abstract}
The high prevalence of Mycobacterium tuberculosis (MTB) despite widely available Bacille Calmette-Guerin (BCG) vaccination may be associated with Mycobacterium avium (M. avium), which may influence the host response to MTB. In this study, we demonstrate that pretreatment of murine macrophages with low-dose Mycobacterium aviumderived lipids (MALs), but not Escherichia coli-derived lipids (ELs), attenuates the clearance of intracellular Mycobacterium bovis BCG (M. bovis BCG) and the production of TNF- $\alpha$, IL-6, IL-12 and nitric oxide (NO) following stimulation with purified protein derivatives (PPD) or heat-inactivated $M$. bovis BCG in vitro. Furthermore, a significant decrease in NF- $\kappa$ B activity was observed in MALs-pretreated RAW264.7 cells that were co-transfected with $\mathrm{pSV}-\beta$-galactosidase and pGL4.32[luc2P/NF-kB-RE/Hygro] prior to stimulation with PPD or heat-inactivated M. bovis BCG. In contrast, IRAK-M, an inhibitor of NF- $\mathrm{kB}$ activation, was increased in these cells. This observed hyporesponsiveness is not related to the expression of Toll-like receptor 2 (TLR2). In conclusion, pretreatment with low-dose MALs can induce hyporesponsiveness to MTB components in murine macrophages.
\end{abstract}

\section{Introduction}

Several hypotheses have been proposed to explain the high prevalence of Mycobacterium tuberculosis (MTB) despite the extensive vaccination with Mycobacterium bovis Bacille Calmette-Guerin (M. bovis BCG) (1). One prominent and experimentally tested hypothesis suggests that exposure to environmental mycobacteria, such as Mycobacterium avium

Correspondence to: Professor Ning Fu, Department of Immunology, School of Basic Medical Science, Southern Medical University, Guangzhou, Guangdong 510515, P.R. China

E-mail: zfzn@fimmu.com; zfzn53@yahoo.com.cn

Key words: Mycobacterium avium-derived lipids, Mycobacterium tuberculosis, macrophage, hyporesponsiveness, NF- $\mathrm{\kappa B}$
(M. avium), interferes with the efficacy of the BCG vaccine (2-5).

M. avium is an opportunistic pathogen that is widely distributed across geographic regions where MTB infections are endemic. Acute infection with $M$. avium can affect host immune function by upregulating the expression of CD95 in T cells, suppressing T cell-macrophage interactions, promoting IL-10 production and reducing the secretion of IL-12, IL-8 and CCL5 (6-11). However, unlike animal models, most people living in MTB-endemic areas are chronically exposed to a low dose of M. avium in the environment, which may lead to asymptomatic or latent infection. The impact of low-dose $M$. avium exposure on host responses, including innate immunity and acquired immunity to subsequent MTB infection, remains unknown. Therefore, we investigated the impact of low-dose exposure to M. avium-derived lipids (MALs) on the host response to MTB, with particular focus on the response of macrophages to M. avium exposure because macrophages are known to be important cellular reservoirs of mycobacteria in the host. Moreover, macrophages play a critical role in the clearance of pathogenic mycobacteria by both the innate and specific immune response (12). MALs are major components of the M. avium cell wall and have been shown to be associated with delayed phagosome maturation and the inhibition of Th1 responses $(13,14)$. In this study, murine macrophages were pretreated with low-dose MALs, followed by stimulation with MTB purified protein derivatives (PPD) or heat-inactivated $M$. bovis $\mathrm{BCG}$, which is routinely used as the vaccine against tuberculosis and as a substitute for MTB in clinical and experimental animal studies. The production of proinflammatory cytokines, including TNF- $\alpha$, IL- 6 and IL-12 as well as nitric oxide (NO), was attenuated, while intracellular M. bovis $\mathrm{BCG}$ growth was not controlled. Moreover, decreased NF- $\mathrm{KB}$ activity and increased levels of IRAK-M suggest that the mechanism responsible for MALs-induced macrophage hyporesponsiveness involves this pathway.

\section{Materials and methods}

Reagents. Iscove's modified Dulbecco's medium (IMDM) was purchased from Gibco (Grand Island, NY, USA); MTB protein purified derivatives (PPD) were purchased from Statens 
Serum Institute (Copenhagen, Denmark). Lipopolysaccharide (LPS, Escherichia coli serotype 2630), Middlebrook 7H9 broth, Middlebrook 7H11 broth, oleic acid-albumin-dextrosecatalase (OADC) and albumin-dextrose-catalase (ADC) were purchased from Sigma (St. Louis, MO, USA). Cell Counting kit-8 (CCK-8) was purchased from Dojindo (Japan). An Annexin V-FITC Apoptosis Detection kit was purchased from KeyGen (Nanjing, China). Mouse cytokine ELISA kits were purchased from either eBioscience or Biolegend (Burlington, CA). Newborn calf serum (NCS) was obtained from Sijiqing Biological Engineering Materials (Hangzhou, China). A Luciferase Assay System kit, pSV- $\beta$-galactosidase control vector and pGL4.32[luc2P/NF- $\mathrm{B}-\mathrm{RE} / \mathrm{Hygro}$ ] vector were purchased from Promega (Madison, WI, USA). Pyrogent Plus Limulus Amoebocyte Lysate kit was obtained from Xiamen Pyrogent Limited Co. (Xiamen, China).

Animals. Specific-pathogen-free (SPF) female BALB/c mice 8-10 weeks of age were purchased from the Experimental Animal Center of Southern Medical University. Animals were maintained at $25^{\circ} \mathrm{C}$ with $50 \%$ humidity and were given commercial feed and sterile water ad libitum. The Ethics Committee for Experimental Animals at Southern Medical University approved all experimental procedures.

Growth of Mycobacteria and Escherichia coli. M. avium and Escherichia coli (E. coli, ATCC25922) were purchased from the National Center for Medical Culture Collections, China. $M$. bovis BCG was obtained from the Chengdu Institute of Biological Products in China. E. coli were grown in nutrient agar medium, and mycobacterial stocks were grown in Middlebrook $7 \mathrm{H} 9$ broth with oleic acid-albumin-dextrosecatalase enrichment at $37^{\circ} \mathrm{C}$ until mid-log phase; aliquots were then frozen at $-80^{\circ} \mathrm{C}$. Frozen $M$. avium and $M$. bovis BCG stocks were thawed and briefly sonicated prior to use. Bacterial numbers were confirmed by plate counting on Middlebrook 7H11 agar plates.

Preparation of MALs and ELs. MALs and E. coli-derived lipids (ELs) were extracted using the Folch procedure as previously described (15-17). Briefly, M. avium and E. coli cultures were autoclaved and harvested by centrifugation; they were then lyophilized and stored at $-20^{\circ} \mathrm{C}$ until lipids were extracted. Lyophilized M. avium or E. coli were homogenized in chloroform-methanol (2:1) to a final volume 20 times that of the sample, followed by agitation in an orbital shaker at room temperature for $2 \mathrm{~h}$. After centrifugation, the liquid phase was collected and washed with 0.2 volume of $0.9 \%$ sodium chloride $(\mathrm{NaCl})$ solution. After vortexing for $30 \mathrm{sec}$, the mixture was centrifuged at $2000 \mathrm{rpm}$ to separate the different phases. The upper phase was removed by siphoning, while the lower chloroform phase that contained lipids was evaporated under a nitrogen stream. Extracts were then weighed and resuspended in dimethyl sulfoxide (DMSO) to a known concentration. Each lipid fraction contained $\leq 0.02$ endotoxin units per $100 \mu \mathrm{g}$ of lipid, as determined using the Pyrogent Plus Limulus Amoebocyte Lysate kit.

Isolation and cultivation of peritoneal macrophages. Isolation, cultivation and identification of mouse peritoneal macrophages were performed as previously described $(18,19)$. Briefly, mice were sacrificed, and peritoneal cells were collected by washing the peritoneal cavity with $5 \mathrm{ml}$ of ice-cold sterile phosphate-buffered saline (PBS), $\mathrm{pH}$ 7.4. Cell suspensions were centrifuged, and the cells were resuspended in IMDM containing $10 \%$ heat-inactivated NCS. Peritoneal cells were incubated at $37^{\circ} \mathrm{C}$ and $5 \% \mathrm{CO}_{2}$ in a humidified chamber for $6 \mathrm{~h}$ to allow macrophages to adhere and spread in culture flasks. Non-adherent cells were removed by decanting followed by three washes with IMDM. The remaining adherent cells were grown in IMDM supplemented with $10 \%$ heat-inactivated NCS and used for experiments.

Measurement of cytokines. Peritoneal macrophages from BALB/c mice or RAW264.7 cells were seeded in 24-well plates at $2 \times 10^{5}$ or $1 \times 10^{5}$ cells/well, respectively. Cells were then treated with or without MALs at concentrations of 0.1 , 0.5 or $1 \mu \mathrm{g} / \mathrm{ml}$ for $48 \mathrm{~h}$. Cells were washed to remove MALs, allowed to recover for $4 \mathrm{~h}$ and then stimulated with PPD

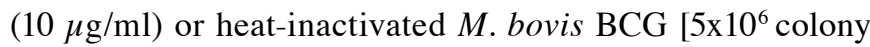
forming units $(\mathrm{CFU}) / \mathrm{ml}]$ for $24 \mathrm{~h}$. Culture supernatants were harvested and assayed for murine TNF- $\alpha$, IL- 6 and IL-12 by ELISA.

Flow cytometry. To detect TLR2 or TLR4 expression, peritoneal macrophages from BALB/c mice were seeded in 6 -well plates at $1 \times 10^{6}$ cells/well and cultured with or without MALs $(1 \mu \mathrm{g} / \mathrm{ml})$ for $48 \mathrm{~h}$. Cells were then washed twice with PBS and harvested from the plates. Cells were labeled with PE-conjugated anti-mouse TLR2 (clone number: T2.5, Biolegend) or Alexa Fluor ${ }^{\circledR}$ 488-conjugated anti-mouse TLR4 (clone number: UT41, eBioscience), washed and then resuspended in ice-cold FACS buffer [PBS, $0.1 \%$ sodium azide, $1 \%$ FCS, $500 \mathrm{mM}$ ethylenediaminetetraacetic acid (EDTA)]. Surface TLR 2 and TLR4 expression was analyzed using a FACSCalibur flow cytometer (BD Biosciences). To evaluate the cytotoxicity of the MALs, RAW264.7 cells were plated in 6-well plates at $2 \times 10^{5}$ cells/well and cultured with or without MALs at $0.1,1$ or $10 \mu \mathrm{g} / \mathrm{ml}$ for $48 \mathrm{~h}$. The level of cell death under each condition was analyzed with the Annexin V-FITC Apoptosis Detection kit, according to the manufacturer's instructions.

Quantitative real-time PCR. Total cellular RNA was extracted with the RNAiso kit (Takara). All the samples were treated with DNase according to the manufacturer's instructions (Qiagen). Quantitative PCR was performed using the Rotor-Gene 3000 system (Corbett Research) according to the manufacturer's instructions. Briefly, mRNA was isolated and reverse transcribed using oligo(dT) as a primer. Quantitative real-time PCR (qRT-PCR) reactions were run on Rotor-Gene 3000 in which $1 \mu \mathrm{l}$ of cDNA was incubated at $50^{\circ} \mathrm{C}$ for $2 \mathrm{~min}$ and at $94^{\circ} \mathrm{C}$ for $10 \mathrm{~min}$, followed by 40 cycles of $94^{\circ} \mathrm{C}$ for $30 \mathrm{sec}, 57^{\circ} \mathrm{C}$ for $30 \mathrm{sec}$ and $72^{\circ} \mathrm{C}$ for $60 \mathrm{sec}$. Fluorescent signals generated during the log-linear phase were used to calculate the relative amount of template DNA.

The primers used in this study are listed in Table I. Data were analyzed using the $2{ }^{-\Delta \Delta C T}$ method; mRNA expression is shown as the fold difference compared to untreated control cells. 
Table I. Primers used in this study.

\begin{tabular}{llll}
\hline Gene & \multicolumn{1}{c}{ Forward primer $\left(5^{\prime} \rightarrow 3^{\prime}\right)$} & \multicolumn{1}{c}{ Reverse primer $\left(5^{\prime} \rightarrow 3^{\prime}\right)$} & GenBank ID \\
\hline GAPDH & TGTGTCCGTCGTGGATCTGA & TTGCTGTTGAAGTCGCAGGA & 126012538 \\
TNF- $\alpha$ & GCCAGGAGGGAGAACAGAAACT & AAGAGGCTGAGACATAGGCACC & 133892368 \\
IL-6 & TCCAGAAACCGCTATGAAGTT & TTCATACAATCAGAATTGCCATT & 13624310 \\
iNOS & GGACATTAACAACAACGGAA & AGTGTCATGCAAAATCTCTCC & 146134510 \\
TLR2 & ACAATAGAGGGAGACGCCTTTT & AGTGTCTGGTAAGGATTTCCCAT & 158749637 \\
TLR4 & TTTATCCAGGTGTGAAATTGA & GCCACATTGAGTTTCTTTAAG & 118130391 \\
IRAK-M & CACAGTTGCTGCTCTTCGAC & CCCAGGACCAGAGCAATTC & 142380077 \\
IL-10 & GCAGCCTTGCAGAAAAGAGAG & TCCTGCATTAAGGAGTCGGTT & 291575143
\end{tabular}

A

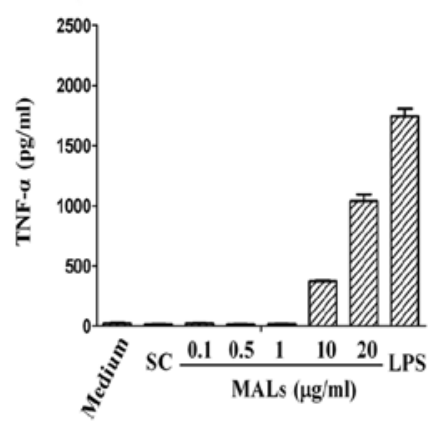

B

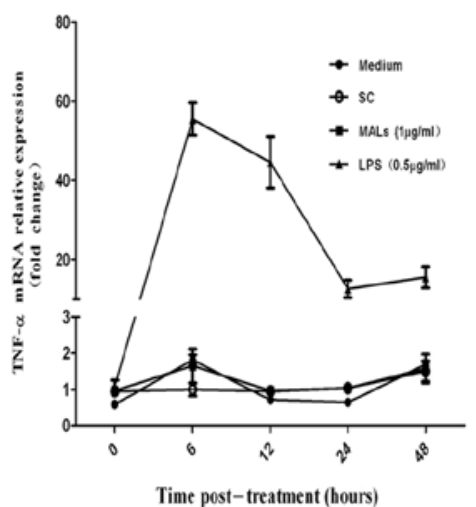

C

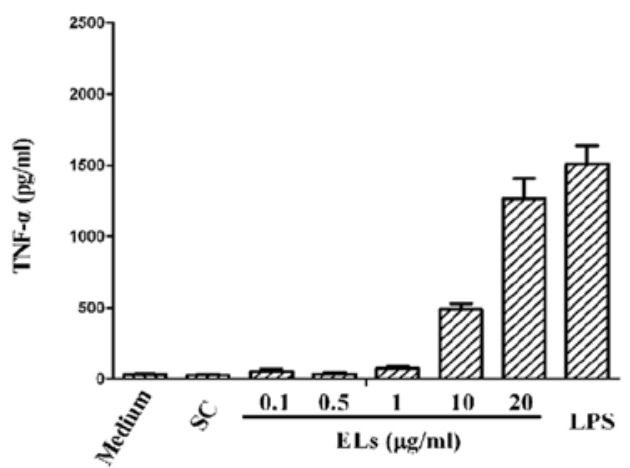

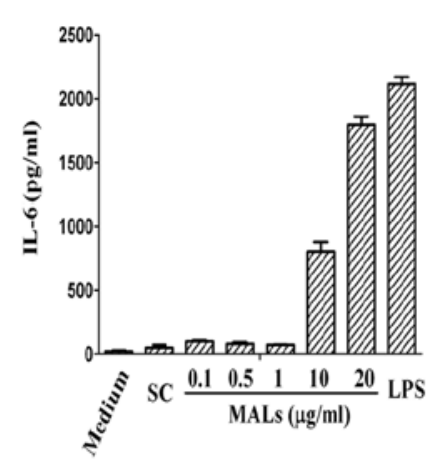
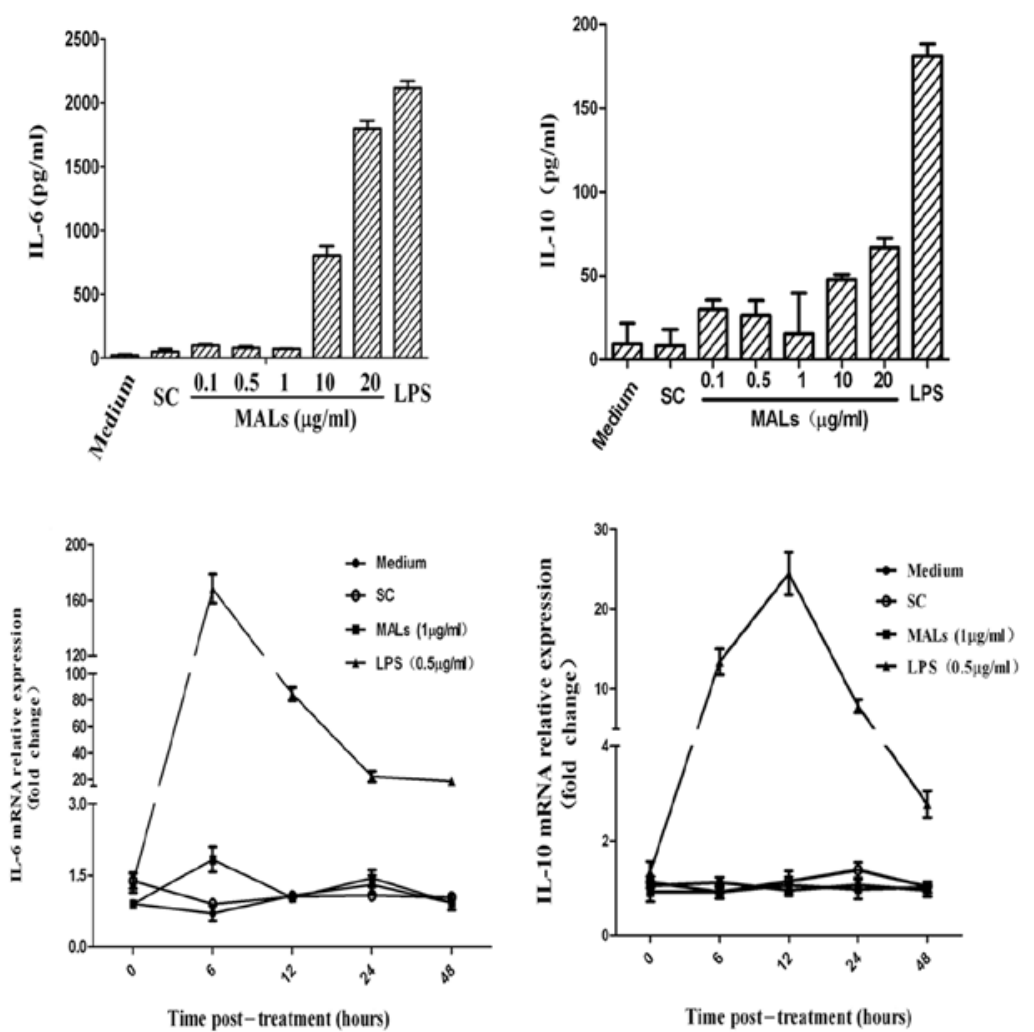

Figure 1. Production of TNF- $\alpha$, IL- 6 and IL-10 by peritoneal macrophages stimulated with MALs or ELs. (A) Murine peritoneal macrophages were stimulated with the indicated concentrations of MALs or $0.5 \mu \mathrm{g} / \mathrm{ml}$ LPS as a positive control for $48 \mathrm{~h}$. Culture supernatants were harvested, and the levels of TNF- $\alpha$, IL-6 and IL-10 were measured by sandwich ELISA. Results are presented as the mean \pm SD of three independent experiments ( $\mathrm{n}=3$ ). (B) Murine peritoneal macrophages were treated with $1 \mu \mathrm{g} / \mathrm{ml}$ MALs or $0.5 \mu \mathrm{g} / \mathrm{ml}$ LPS, as a positive control, for the times indicated; mRNA levels of TNF- $\alpha$, IL-6 and IL-10 were determined by qRT-PCR. Average TNF- $\alpha$, IL- 6 and IL-10 mRNA expression \pm SD (in relative units) from three independent experiments are shown. (C) Murine peritoneal macrophages were stimulated with the indicated concentrations of ELs or $0.5 \mu \mathrm{g} / \mathrm{ml} \mathrm{LPS}$ as a positive control for $48 \mathrm{~h}$. Culture supernatants were harvested, and the levels of TNF- $\alpha$ and IL- 6 were measured by sandwich ELISA. Results are presented as mean \pm SD of three independent experiments $(\mathrm{n}=3)$. SC, solvent control (0.005\% DMSO). 
A

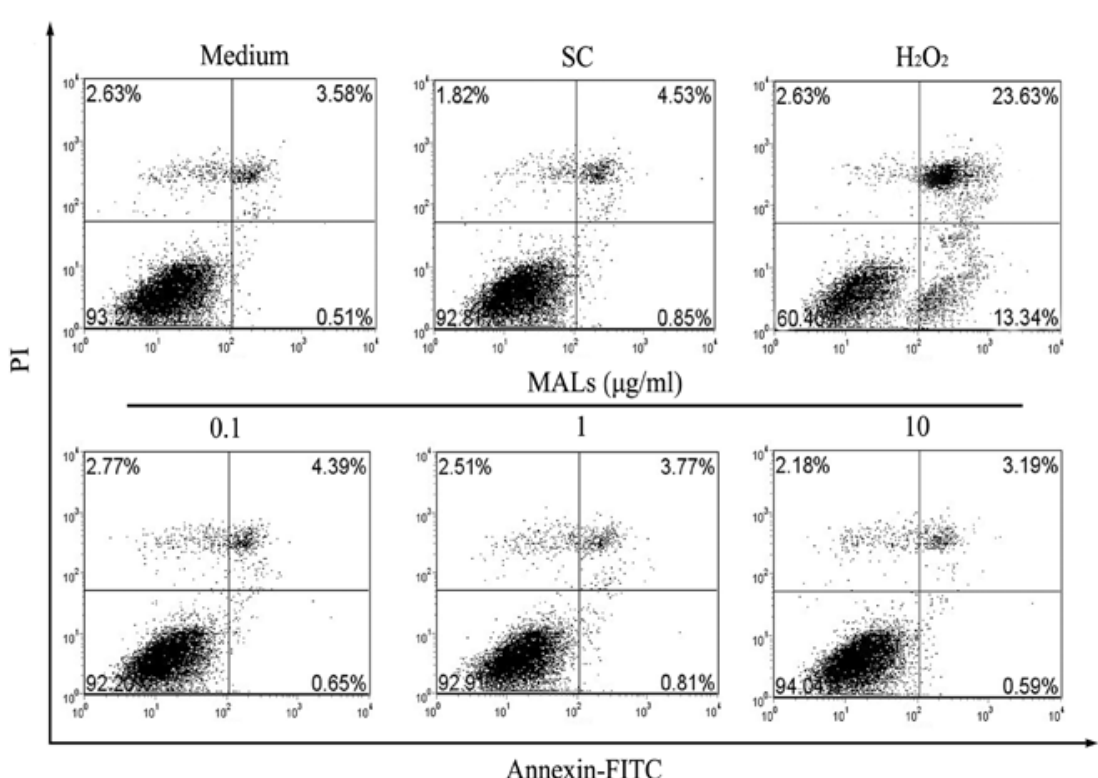

B

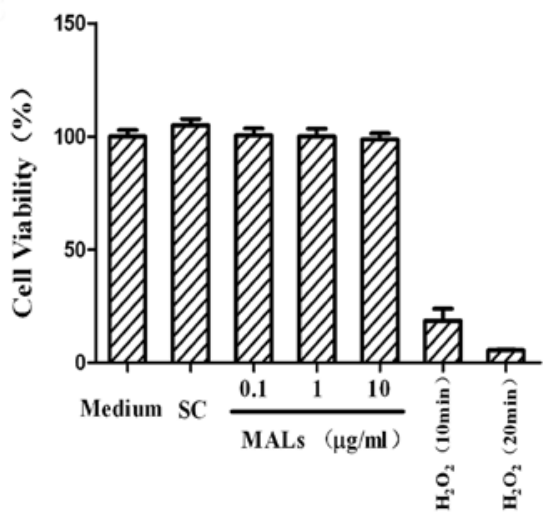

Figure 2. Cytotoxic effects of MALs on either RAW264.7 cells or murine peritoneal macrophages. (A) RAW264.7 cells were treated with the indicated concentrations of MALs for $48 \mathrm{~h}$ prior to staining with FITC-Annexin V and PI to assess cell viability. Culture with $\mathrm{H}_{2} \mathrm{O}_{2}\left(6 \mu 130 \% \mathrm{H}_{2} \mathrm{O}_{2} / 10 \mathrm{ml}\right.$ medium) was used as a positive control. (B) Murine peritoneal macrophages were treated with the indicated concentrations of MALs for $48 \mathrm{~h}$ prior to determination of cell viability with the CCK-8. Culture with $\mathrm{H}_{2} \mathrm{O}_{2}$ was used as a positive control. Data are representative of three independent experiments with similar results. SC, solvent control $(0.005 \%$ DMSO).

Nitrite assay for the evaluation of nitric oxide. Murine peritoneal macrophages were seeded at $2 \times 10^{5}$ cells/well in 24 -well plates and treated with or without MALs at concentrations of $0.1,0.5$ and $1 \mu \mathrm{g} / \mathrm{ml}$ for $48 \mathrm{~h}$. Cells were washed to remove MALs and allowed to recover for $4 \mathrm{~h}$ before PPD $(10 \mu \mathrm{g} / \mathrm{ml})$ or heat-inactivated $M$. bovis BCG $\left(5 \times 10^{6} \mathrm{CFU} / \mathrm{ml}\right)$ stimulation for $24 \mathrm{~h}$. Total nitrite levels in the media were measured using the Griess reagent [1\% sulfanilamide and $0.1 \% \mathrm{~N}$-(1-naphthyl) ethylenediamine in $2 \%$ phosphoric acid]; assays were performed according to the manufacturer's directions.

Measurement of nuclear factor- $\kappa B$ activity. Nuclear factor- $\mathrm{KB}(\mathrm{NF}-\kappa \mathrm{B})$ activity in RAW264.7 cells was detected using an NF- $\mathrm{BB}$-luciferase reporter vector (pGL4.32[luc2P/ NF- $\kappa B-R E / H y g r o] ~ v e c t o r) . ~ B r i e f l y, ~ 5 \times 10^{6}$ RAW264.7 cells were transiently co-transfected with pSV- $\beta$-galactosidase and

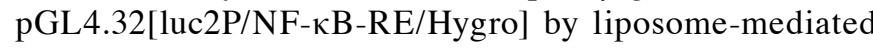
transfection at a DNA/lipid ratio of $1 \mu \mathrm{g}$ of each plasmid DNA/ $2 \mu 1$ of Lipofectamine 2000 . The cells were allowed to recover for $24 \mathrm{~h}$ prior to being plated in 24 -well plates at
$1 \times 10^{5}$ cells/well and were cultured with or without MALs at $0.1,0.5$ or $1 \mu \mathrm{g} / \mathrm{ml}$ for $48 \mathrm{~h}$. After a $4 \mathrm{~h}$ recovery period, the cells were stimulated with PPD $(10 \mu \mathrm{g} / \mathrm{ml})$ or heat-inactivated M. bovis $\mathrm{BCG}\left(5 \times 10^{6} \mathrm{CFU} / \mathrm{ml}\right)$ for $12 \mathrm{~h}$. Luciferase activity was measured on a Victor 4 multi-labeled counter using the Luciferase Assay System kit according to manufacturer's instructions. The intensity of luciferase activity in these cells was normalized to their $\beta$-galactosidase activity which was used as an internal control. Luciferase activity was expressed as a fold increase.

Western blotting. Cytoplasmic protein extracts separated from cells were loaded immediately on sodium dodecyl sulfate polyacrylamide gels (SDS-PAGE) after boiling for $5 \mathrm{~min}$, as previously described by Vavricka et al (20). Samples were run by electrophoresis and then transferred to polyvinylidene difluoride membranes (PVDF) (Millipore, Bedford, MA, USA). PVDF Membranes were blocked with $5 \%$ bovine serum albumin (BSA) at room temperature for $1 \mathrm{~h}$ and then probed with antibodies specific for IRAK-M and GAPDH, followed 
A

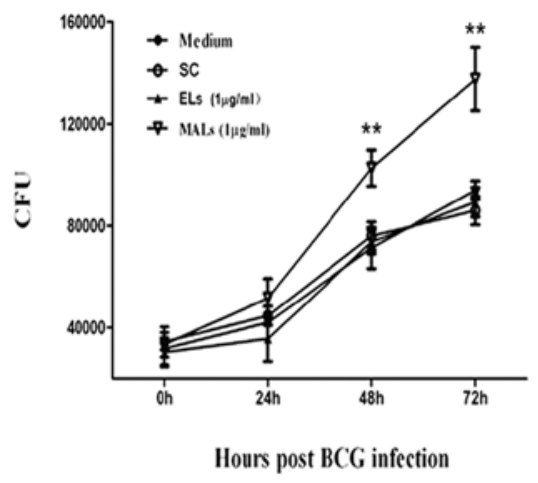

B

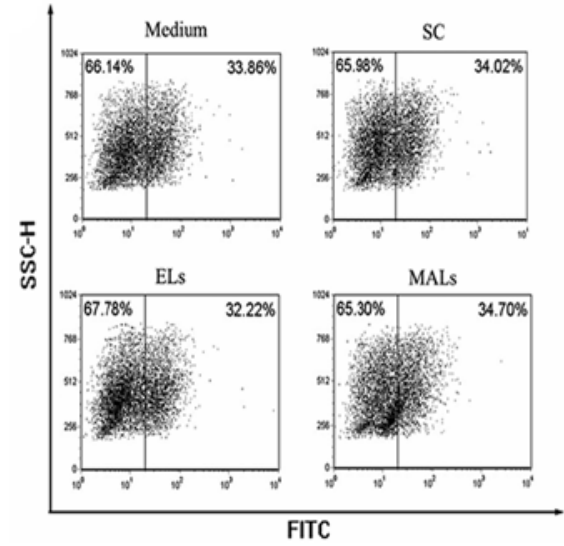

C

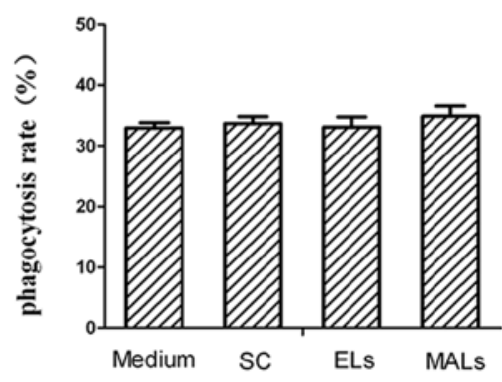

Figure 3. Effects of pretreatment with low-dose MALs on the intracellular growth of M. bovis BCG in vitro. (A) Murine peritoneal macrophages were pretreated with $1 \mu \mathrm{g} / \mathrm{ml}$ MALs, $1 \mu \mathrm{g} / \mathrm{ml}$ ELs, SC or medium alone for $48 \mathrm{~h}$, allowed to recover for $4 \mathrm{~h}$, and then infected with $M$. bovis BCG for $2 \mathrm{~h}$. After co-incubation, extracellular bacteria were removed. Cells were lysed with $0.1 \%$ Triton X-100 at indicated time points, and cell lysates were plated on Middlebrook $7 \mathrm{H} 11$ agar for 21 days of culture. Results are presented as mean $\pm \mathrm{SD}$ of three independent experiments ( $\mathrm{n}=3$ ). Significant differences $\left({ }^{* *} \mathrm{P}<0.01\right)$ compared to control cultures treated with SC at the same time point are indicated. (B and C) Pretreatment of murine peritoneal macrophages with MALs did not alter macrophage phagocytosis. Murine peritoneal macrophages were treated with MALs, ELs or SC for 48 h, recovered for $4 \mathrm{~h}$, and then co-cultured with FITC-labeled M. bovis $\mathrm{BCG}$ for $3 \mathrm{~h}$. They were then washed 5 times with PBS to remove extracellular FITC-labeled M. bovis BCG, and phagocytosis rates were determined by flow cytometry. Results are presented as mean \pm SD of three independent experiments ( $\mathrm{n}=3)$. SC, solvent control (0.005\% DMSO).

by the addition of the appropriate horseradish peroxidase (HRP)-labeled goat anti-rabbit/mouse antibodies, respectively. The chemiluminescent signal was detected using the Novex ECL kit from Invitrogen (Shanghai, China).

Statistical analysis. Data are presented as the mean \pm SD Comparisons between groups were performed using an unpaired Student's t-test, and $\mathrm{P}<0.05$ was considered statistically significant.

\section{Results}

Pretreatment of murine peritoneal macrophages with lowdose MALs reduces the clearance of intracellular M. bovis $B C G$ in vitro. In order to investigate whether low-dose exposure to MALs impacts macrophage responses to MTB, we determined that MALs in doses $\leq 1 \mu \mathrm{g} / \mathrm{ml}$ could not induce a detectable proinflammatory response (Fig. 1A and B). ELs inducing an equivalent proinflammatory response to MALs were used as a non-mycobacterium lipid control (Fig. 1C). We also confirmed that $1 \mu \mathrm{g} / \mathrm{ml}$ MALs in culture did not influence the viability of macrophages (Fig. 2). To determine whether pretreatment with low-dose MALs influences the intracellular growth of $M$. bovis BCG in vitro, murine peritoneal macrophages pretreated with MALs, ELs or solvent control (SC) were infected with M. bovis BCG. As shown in Fig. 3, pretreatment of murine peritoneal macrophages with MALs promoted the intracellular growth of $M$. bovis BCG in macrophages (Fig. 3A) but did not alter macrophage phagocytosis (Fig. 3B and $\mathrm{C}$ ). These results indicate that pretreatment with MALs attenuates the ability of murine peritoneal macrophages to suppress the growth of M. bovis BCG.

Exposure to low-dose MALs reduces secretion of TNF- $\alpha$, IL- 6 and IL-12 by macrophages stimulated with PPD or heat-inactivated M. bovis BCG in vitro. As TNF- $\alpha$ is required for the control of mycobacterial growth and as TNF- $\alpha$ knockout mice exhibit an increased bacillary load and a higher mortality in experimental infections with MTB (21), we examined TNF- $\alpha$ production by macrophages pretreated with MALs. Peritoneal macrophages that had been pretreated with MALs and stimulated with MTB components, PPD and heat-inactivated $M$. bovis BCG exhibited attenuated secretion of cytokines, including TNF- $\alpha$, IL-6 and IL-12 (Fig. 4).

Pretreatment of macrophages with low-dose MALs attenuates nitric oxide production induced by PPD or heat-inactivated $M$. bovis $B C G$. Nitric oxide (NO) is an important intermediate in the control of M. tuberculosis because it facilitates the killing activity of macrophages. Results in Fig. 5A show that NO production by murine macrophages that had been pretreated with low-dose MALs prior to PPD stimulation was significantly reduced compared to that of macrophages pretreated with SC or ELs $(\mathrm{P}<0.05)$. As NO production is regulated by the expression of inducible NO synthase 2 (iNOS), we also analyzed iNOS expression at the transcriptional level. Pretreatment with MALs significantly reduced iNOS mRNA levels in macrophages subsequently activated with PPD or heat-inactivated $M$. bovis BCG compared to macrophages pretreated with SC or ELs $(\mathrm{P}<0.05)$ (Fig. 5B).

Pretreatmentwithlow-dose MALs decreases nuclearfactor- $\kappa B$ $(N F-\kappa B)$ activity induced by PPD or heat-inactivated M. bovis $B C G$ in RAW264.7 cells. Because the NF- $\kappa \mathrm{B}$ signaling pathway is critical for the production of proinflammatory cytokines and NO, we further explored whether the reduced production of cytokines and NO in murine macrophages pretreated with MALs was associated with impaired NF- $\kappa \mathrm{B}$ activity. To evaluate NF- $\kappa \mathrm{B}$ activity, murine macrophage RAW264.7 cells were co-transfected with pGL4.32[luc2P/NF-кB-RE/ 
A

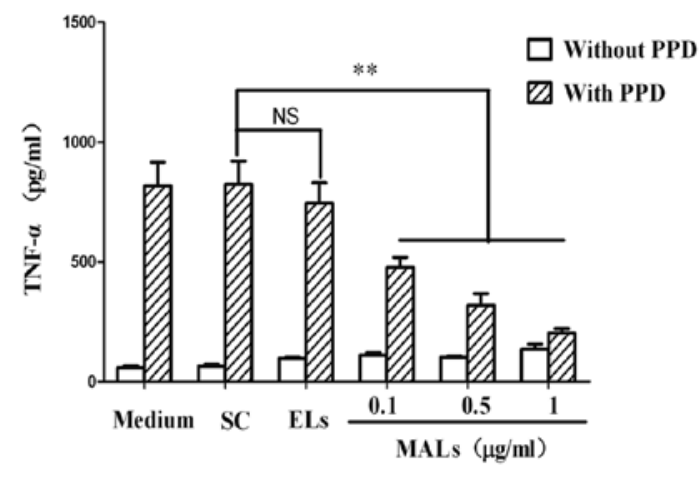

C

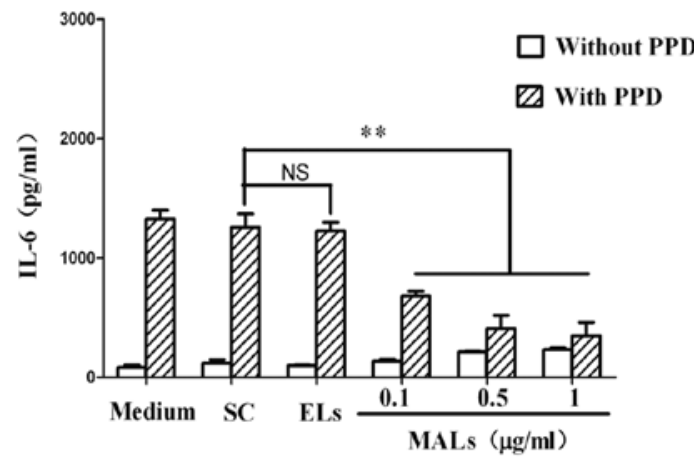

$\mathbf{E}$

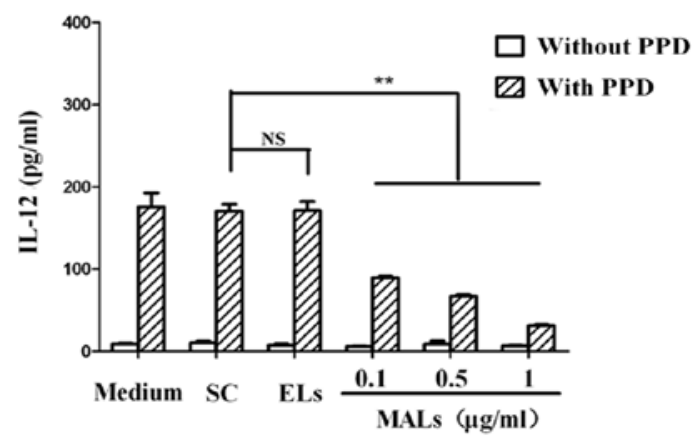

B

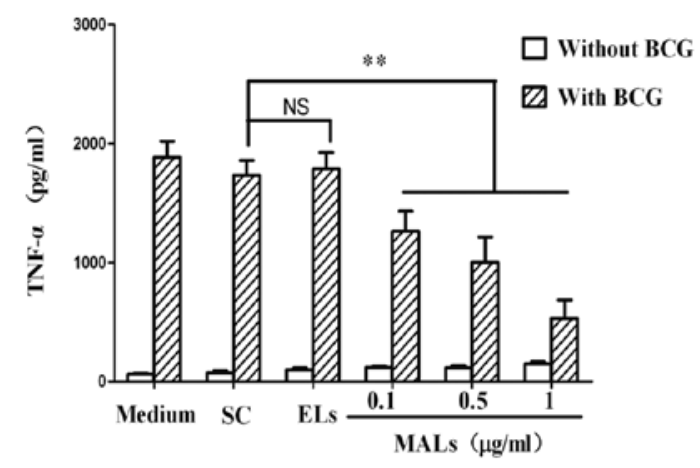

D

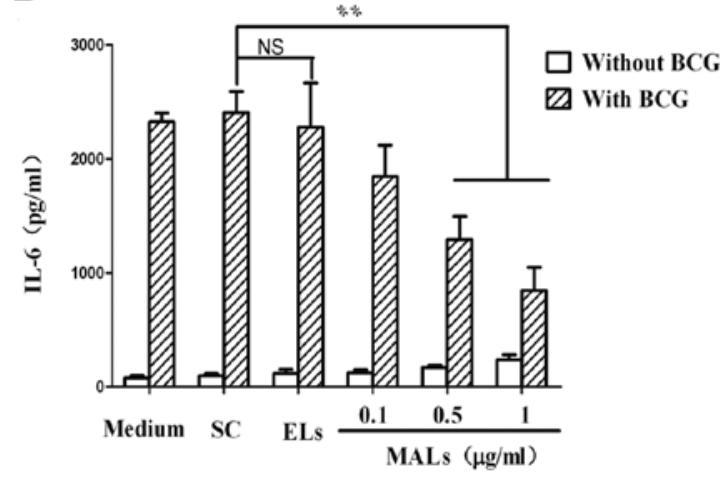

F

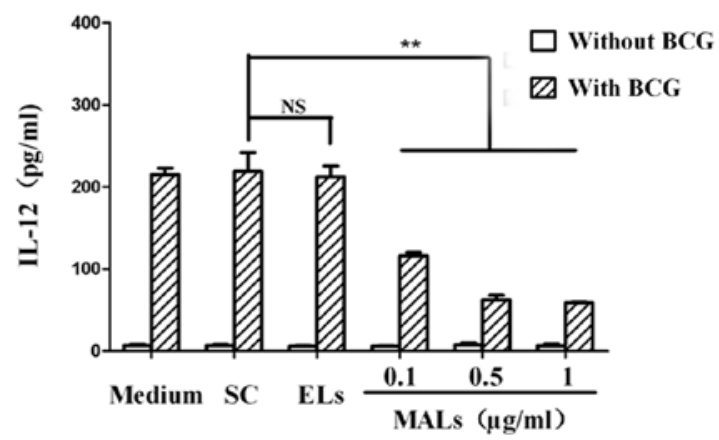

Figure 4. Exposure to low-dose MALs reduces TNF- $\alpha$, IL-6 and IL-12 production by murine macrophages stimulated with PPD or heat-inactivated $M$. bovis BCG in vitro. Murine peritoneal macrophages were pretreated with MALs, ELs or SC for $48 \mathrm{~h}$, allowed to recover for $4 \mathrm{~h}$, and then stimulated for $24 \mathrm{~h}$ with $10 \mu \mathrm{g} / \mathrm{ml}$ PPD (A, C and E) or $5 \times 10^{6} \mathrm{CFU} / \mathrm{ml}$ heat-inactivated $M$. bovis BCG (B, D and F). Culture supernatants were harvested, and the levels of TNF- $\alpha$, IL- 6 and IL-12 were measured by sandwich ELISA. One representative experiment of three is shown. NS, not significant; ${ }^{* *} \mathrm{P}<0.01$ compared to control cultures treated with SC; SC, solvent control (0.005\% DMSO).

Hygro] and pSV- $\beta$-galactosidase. Cells were then pretreated with MALs for $48 \mathrm{~h}$ prior to PPD or heat-inactivated $M$. bovis BCG stimulation, and luciferase activity was measured $12 \mathrm{~h}$ later. Results are presented as the mean fold of induction over the values obtained from unstimulated samples. As shown in Fig. 6, a significant decrease in luciferase activity was observed in transfected cells that had been pretreated with MALs prior to stimulation $(\mathrm{P}<0.01)$.

Attenuation of responses to PPD or heat-inactivated M. bovis $B C G$ in murine macrophages induced by MALs is associated with increased IRAK-M. IRAK-M is an inhibitory protein of the $N F-\kappa B$ signaling pathway. We found a significant increase in IRAK-M mRNA expression in murine peritoneal macrophages and RAW264.7 cells treated by MALs over a 48-h period (Figs. 7A and B). Further, we examined IRAK-M protein expression by western blot analysis. As shown in Fig. 7C, treatment with MALs induced an obvious increase in IRAK-M protein compared to SC- or ELs-treated controls.

Pretreatment with MALs does not decrease the expression of TLR2 and TLR4 on macrophages stimulated with PPD or heat-inactivated $M$. bovis $B C G$. Macrophages mainly sense mycobacterial components through pattern recognition receptors such as TLR2 and TLR4 (22), which can initiate the inflammatory response. In this study, we show that the response of macrophages stimulated with PPD and heat-inactivated $M$. bovis BCG are also TLR2-dependent. 
A
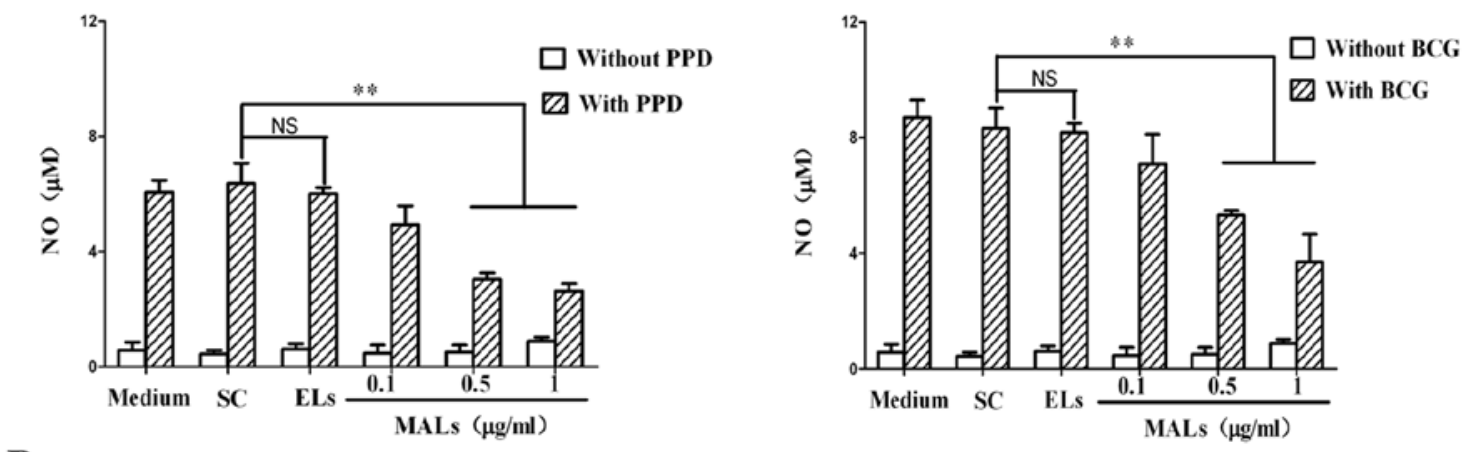

B
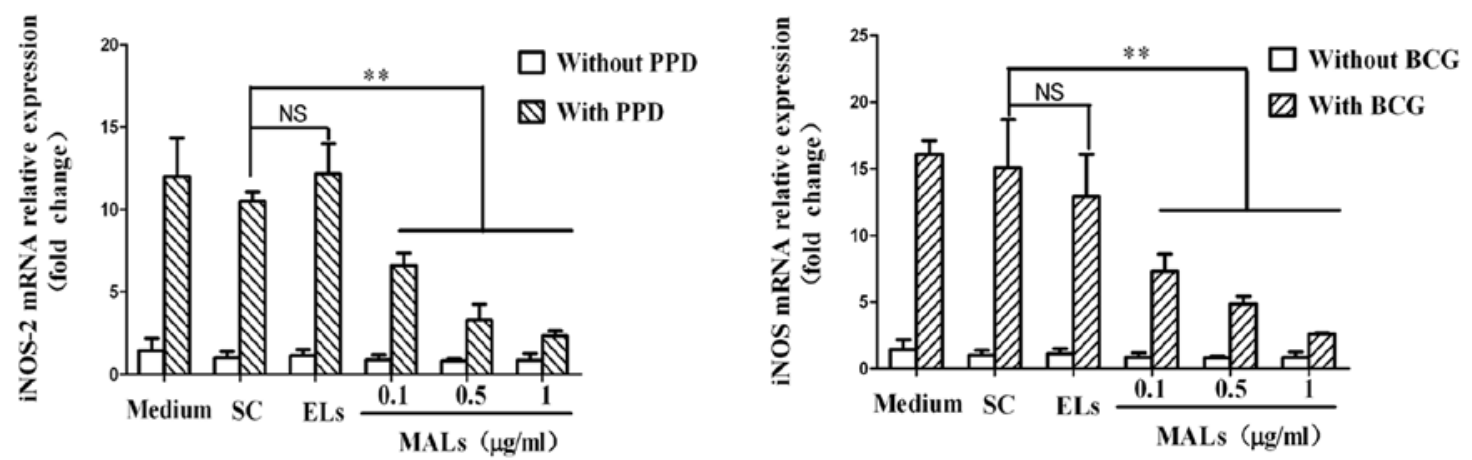

Figure 5. Pretreatment with low-dose MALs attenuates nitric oxide production (NO) in murine peritoneal macrophages stimulated with PPD or heat-inactivated M. bovis BCG. (A) Murine peritoneal macrophages were pretreated with MALs, ELs or SC alone for $48 \mathrm{~h}$, allowed to recover for $4 \mathrm{~h}$, and then stimulated with $10 \mu \mathrm{g} / \mathrm{ml}$ PPD or $5 \times 10^{6} \mathrm{CFU} / \mathrm{ml}$ heat-inactivated M. bovis BCG for $24 \mathrm{~h}$. Culture supernatants were harvested, and the levels of nitrite were measured by the Griess reaction. One representative experiment of three is shown. (B) Murine peritoneal macrophages were pretreated for $48 \mathrm{~h}$ in the presence of the indicated concentration of MALs, ELs or SC alone and then stimulated for $6 \mathrm{~h}$ with $10 \mu \mathrm{g} / \mathrm{ml}$ PPD or 5x10 ${ }^{6} \mathrm{CFU} / \mathrm{ml}$ heat-inactivated M. bovis BCG. Isolated RNA was reverse transcribed, and qRT-PCR was performed to determine iNOS mRNA expression. The mean \pm SD (in relative units) of the iNOS mRNA expression from three independent experiments is shown. NS, not significant; ${ }^{* *} \mathrm{P}<0.01$ compared to cells treated with SC alone; SC, solvent control ( $0.005 \%$ DMSO).

$\mathbf{A}$

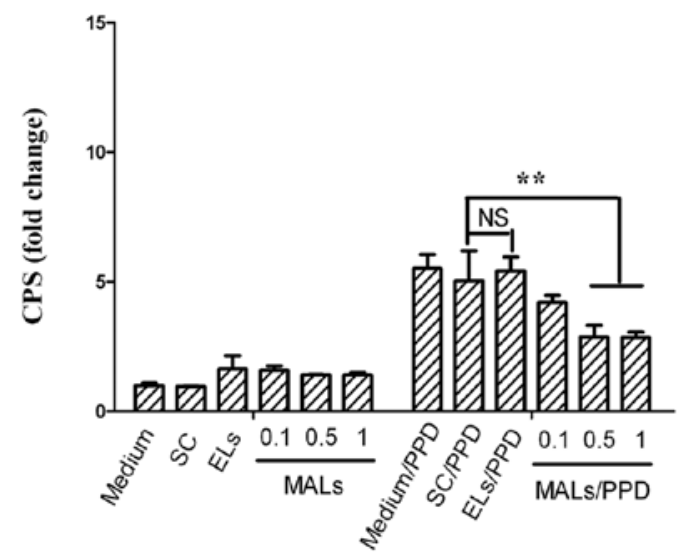

B

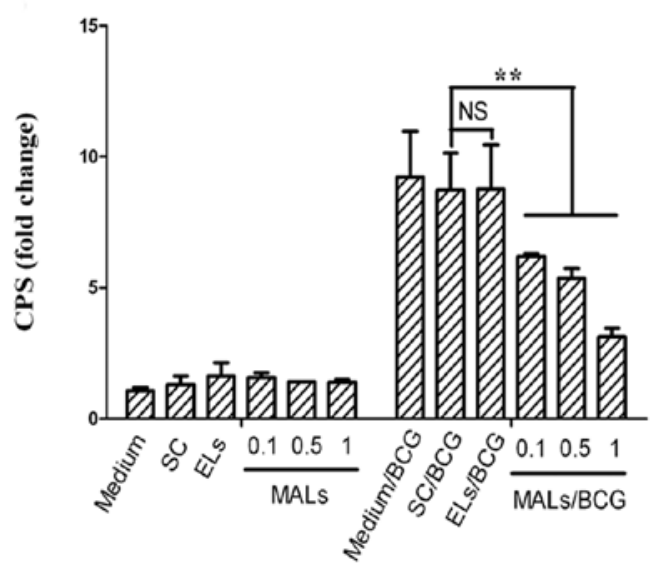

Figure 6. Pretreatment with low-dose MALs decreases NF- $\mathrm{KB}$ activity induced by PPD or heat-inactivated M. bovis BCG in RAW264.7 cells. RAW264.7 cells were transiently co-transfected with pGL4.32[luc2P/NF-kB-RE/Hygro] and pSV- $\beta$-galactosidase by liposomal-mediated transfection at a DNA/lipid ratio of $1 \mu \mathrm{g}$ of each plasmid DNA/2 $\mu \mathrm{l}$ of Lipofectamine 2000 . After a 24 -h recovery period, the cells were plated in 24 -well plates at $1 \times 10^{5}$ cells/well and pretreated for $48 \mathrm{~h}$ with the indicated concentrations of MALs, ELs or SC alone. The cells were allowed to recover for $4 \mathrm{~h}$ and then stimulated for $12 \mathrm{~h}$ with $10 \mu \mathrm{g} / \mathrm{ml}$ PPD (A) or $5 \times 10^{6} \mathrm{CFU} / \mathrm{ml}$ heat-inactivated M. bovis BCG (B). Luciferase activity and $\beta$-galactosidase activity were measured from different aliquots of the same lysate. The intensity of the measured luciferase reactions was normalized to their $\beta$-galactosidase activity, which was used as an internal control. NS, not significant; ${ }^{* *} \mathrm{P}<0.01$ compared to cells treated with SC alone; SC, solvent control (0.005\% DMSO).

Indeed, the production of TNF- $\alpha$ and IL-6 in response to PPD was significantly inhibited by pretreatment with anti-TLR2 antibodies but not with anti-TLR4 antibodies or isotype-matched murine immunoglobulin used as a control (Fig. 8A). These findings suggest that PPD-induced activation of macrophages and the production of proinflammatory 
A
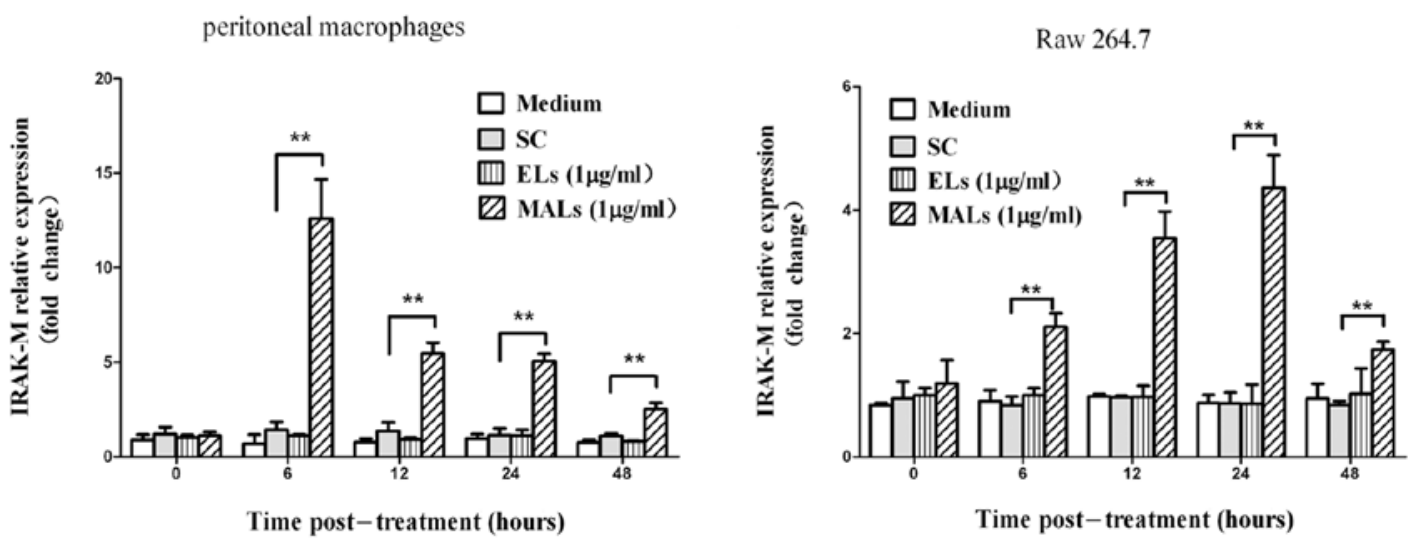

B

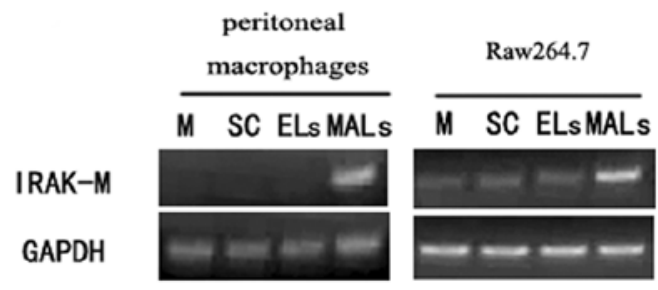

C

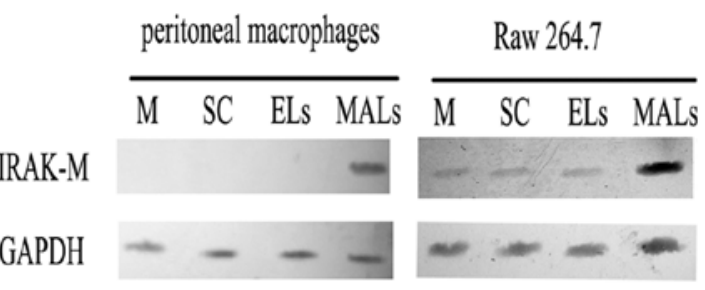

Figure 7. Murine macrophages upregulate IRAK-M upon treatment with MALs. (A) Murine peritoneal macrophages or RAW264.7 cells were cultured with $1 \mu \mathrm{g} / \mathrm{ml}$ MALs, $1 \mu \mathrm{g} / \mathrm{ml}$ ELs, SC or medium alone for the indicated times. Isolated RNA was reverse transcribed, and qRT-PCR was performed to determine IRAK-M expression. The mean \pm SD (in relative units) of IRAK-M mRNA expression from three independent experiments is shown. (B) Murine peritoneal macrophages or RAW264.7 cells were cultured with $1 \mu \mathrm{g} / \mathrm{ml}$ MALs, $1 \mu \mathrm{g} / \mathrm{ml}$ ELs, SC or medium alone for $6 \mathrm{~h}$. RNA was isolated, reverse transcribed and amplified for GAPDH and IRAK-M. Samples were run on a $1 \%$ agarose gel. (C) Murine peritoneal macrophages or RAW264.7 cells were cultured with $1 \mu \mathrm{g} / \mathrm{ml}$ MALs, $1 \mu \mathrm{g} / \mathrm{ml}$ ELs or SC for $48 \mathrm{~h}$. Cell lysates were analyzed by western blot analysis for the expression of IRAK-M. GAPDH served as the control. ${ }^{* *} \mathrm{P}<0.01$ compared to cells treated with SC alone; SC, solvent control (0.005\% DMSO).

cytokines are mainly induced via TLR2 but not TLR4. Therefore, we investigated whether MALs-induced attenuated responses to PPD or heat-inactivated $M$. bovis BCG in macrophages would be TLR2-dependent or TLR4dependent by examining the effect of low-dose MALs on TLR 2 and TLR4 expression. Unexpectedly, the expression levels of TLR2 on murine peritoneal macrophages treated with MALs for $48 \mathrm{~h}$ was higher than those of the control. Moreover, TLR 2 and TLR4 expression levels induced by PPD or heat-inactivated M. bovis BCG were not decreased by pretreatment with MALs (Fig. 8B and C). To further confirm this phenomenon, transcription levels of TLR2 and TLR4 were analyzed over $48 \mathrm{~h}$ of pretreatment with MALs using quantitative real-time PCR. As shown in Fig. 8D, the expression of TLR2 was increased and maintained at a high level for up to $12 \mathrm{~h}$ and decreased to lower levels at 24 and $48 \mathrm{~h}$ after simulation with MALs. In contrast, TLR4 expression was not increased by the various stimuli, including ELs. These results suggest that the attenuation of responses to PPD or heat-inactivated M. bovis BCG in macrophages pretreated with MALs is not associated with attenuated TLR2 or TLR4 expression.

\section{Discussion}

In recent years, the components of various microbes, including peptidoglycan (PGN), LPS, zymosan and muramyl dipeptide (MDP), have been reported to induce a tolerance in the host (23-25). It is noteworthy that tolerance in the above studies was defined as attenuated proinflammatory cytokine production and enhanced clearance of bacteria. For example, pretreatment with PGN or LPS improved bacterial clearance but decreased the production of TNF- $\alpha$ and IFN- $\gamma$ in mice challenged with Staphylococcus aureus (S. aureus) or Pseudomonas aeruginosa (P. aeruginosa) (25-28). In the present study, however, in contrast to the tolerance induced by PGN and LPS, the tolerance induced by treatment with MALs was characterized by the attenuation both in cytokine production and in the clearance of intracellular M. bovis BCG growth, which could be considered as hyporesponsiveness to tuberculosis and as a possibility to increase the susceptibility to tuberculosis.

It is well known that mycobacteria can invade macrophages and establish persistent intracellular infection. The control or clearance of intracellular mycobacterial infection is predominately dependent on macrophage activation induced by TNF- $\alpha$ or IFN- $\gamma$ and the subsequent production of bactericidal mediators such as NO. The critical roles of TNF- $\alpha$ and NO in the control of mycobacterial infections have been well documented in the literature (29-32). Thus, attenuation of TNF- $\alpha$ and NO secretion due to induced hyporesponsiveness by exposure to MALs may cause a failure or reduction in mycobacterial clearance, thereby making the host more susceptible to microbial infections. Unlike mycobacterial infections, there is no persis- 

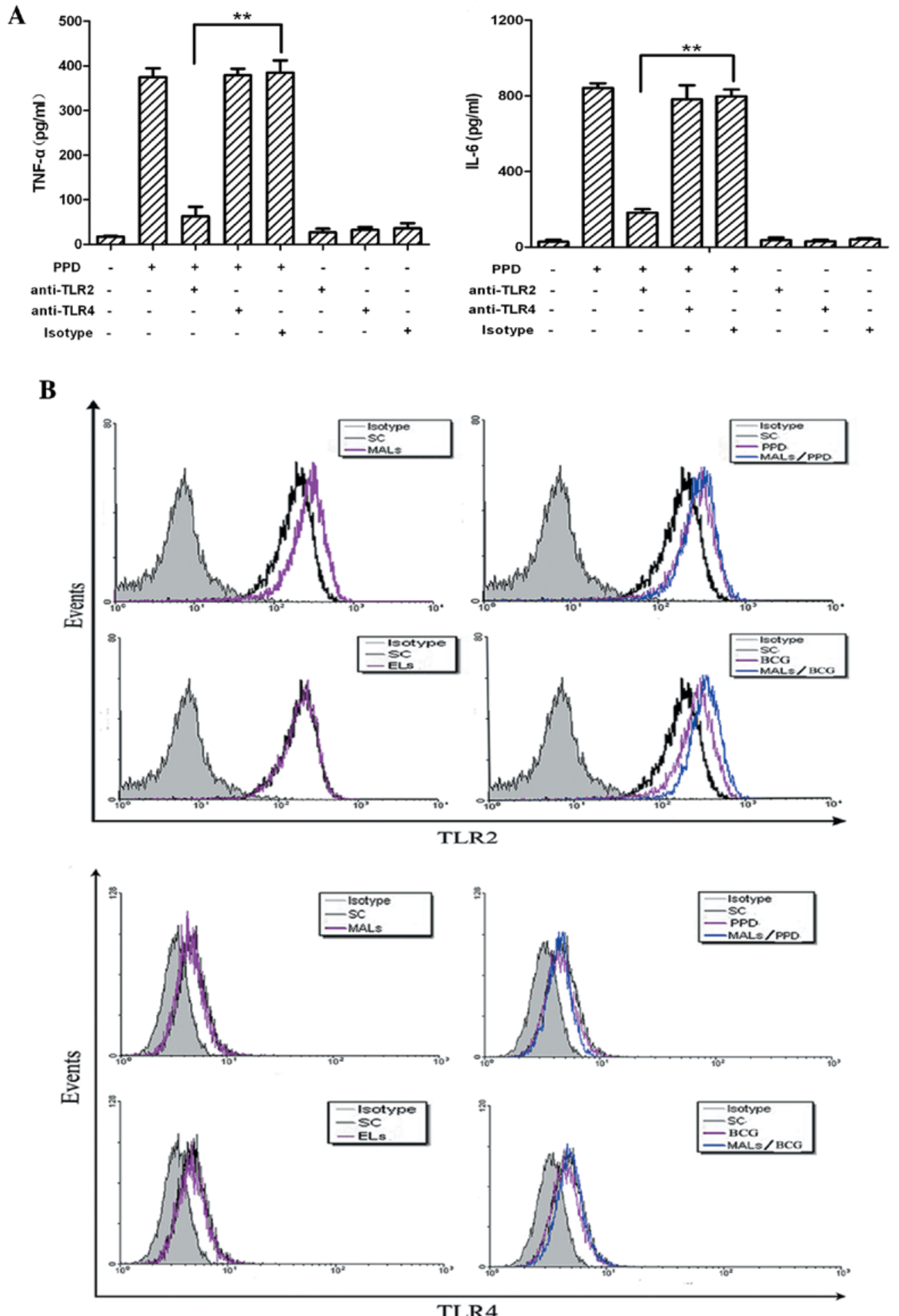

Figure 8. Effects of MALs on TLR2 and TLR4 expression in murine macrophages. (A) Murine peritoneal macrophages were pretreated with anti-TLR2 monoclonal antibodies (mAb), anti-TLR4 mAb or isotype control IgG $(20 \mu \mathrm{g} / \mathrm{ml})$, followed by stimulation with $10 \mu \mathrm{g} / \mathrm{ml}$ PPD for $24 \mathrm{~h}$. Next, supernatants were harvested for cytokine measurements (TNF- $\alpha$ and IL-6) by ELISA. Data are presented as the mean \pm SD and are representative of three independent experiments. Significant differences $\left({ }^{* *} \mathrm{P}<0.01\right)$ compared to the isotype control are indicated. (B) Murine peritoneal macrophages were treated with $1 \mu \mathrm{g} / \mathrm{ml}$ MALs, $1 \mu \mathrm{g} / \mathrm{ml} \mathrm{ELs,} \mathrm{SC,} 10 \mu \mathrm{g} / \mathrm{ml}$ PPD or $5 \times 10^{6} \mathrm{CFU} / \mathrm{ml}$ heat-inactivated M. bovis BCG for $48 \mathrm{~h}$ or were pretreated with $1 \mu \mathrm{g} / \mathrm{ml}$ MALs for $48 \mathrm{~h}$ and then allowed to recover for $4 \mathrm{~h}$ followed by stimulation with $10 \mu \mathrm{g} / \mathrm{ml} \mathrm{PPD} \mathrm{or} 5 \times 10^{6} \mathrm{CFU} / \mathrm{ml}$ heat-inactivated $M$. bovis BCG for $24 \mathrm{~h}$. Cells were then labeled with anti-TLR2 $\mathrm{mAb}$ (PE-T2.5) or anti-TLR4 mAb (Alexa Fluor ${ }^{\circledR}$ 488- anti-mouse CD284) and examined by flow cytometry. Data shown are fluorescence intensity vs. cell number.

tent intracellular growth in phagocytes, and TNF- $\alpha$ or NO are not critically required for pathogen clearance in infections with S. aureus and P. aeruginosa. Rather, controlling these infections relies on specific antibody production and increased numbers of phagocytes (27). These phenomena suggest that macrophages use different mechanisms, both in defense and 
C

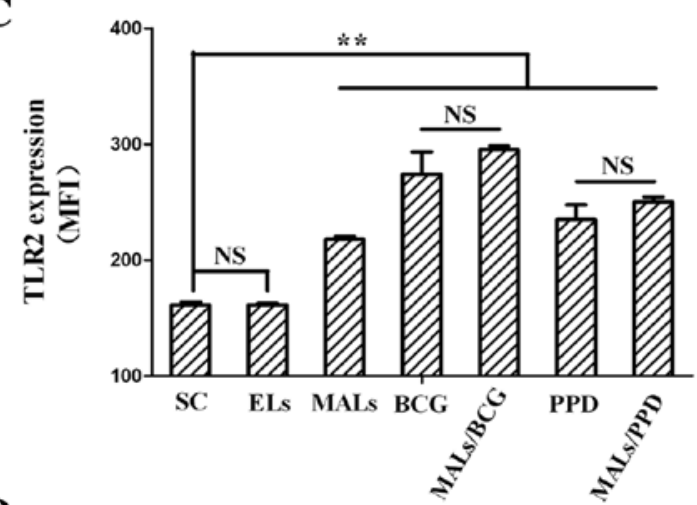

D

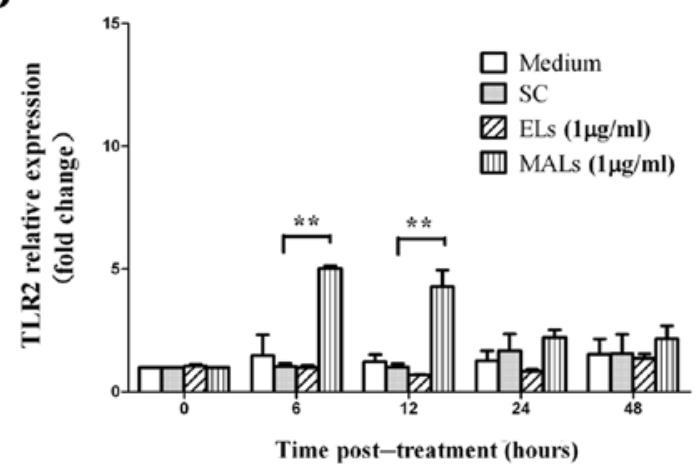

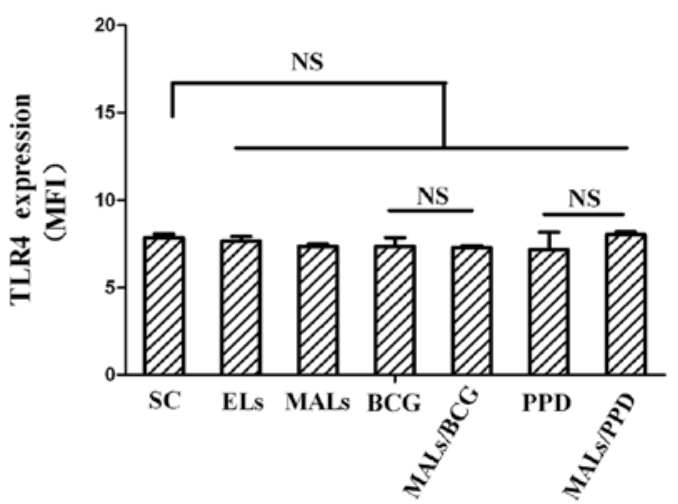

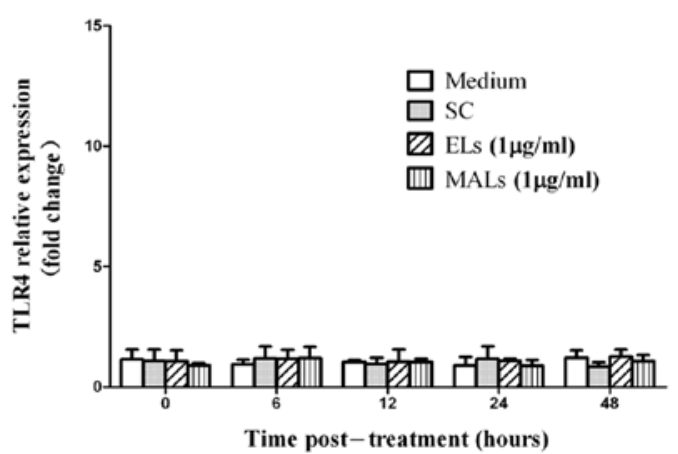

Figure 8. Continued. (C) Murine peritoneal macrophages were treated with $1 \mu \mathrm{g} / \mathrm{ml}$ MALs, $1 \mu \mathrm{g} / \mathrm{ml}$ ELs, SC, $10 \mu \mathrm{g} / \mathrm{ml} \mathrm{PPD}$ or $5 \mathrm{x} 10^{6} \mathrm{CFU} / \mathrm{ml}$ heat-inactivated M. bovis BCG for $48 \mathrm{~h}$ or were pretreated with $1 \mu \mathrm{g} / \mathrm{ml}$ MALs for $48 \mathrm{~h}$ and then allowed to recover for $4 \mathrm{~h}$ followed by stimulation with $10 \mu \mathrm{g} / \mathrm{ml} \mathrm{PPD}$ or $5 \times 10^{6} \mathrm{CFU} / \mathrm{ml}$ heat-inactivated $M$. bovis BCG for $24 \mathrm{~h}$. Cells were then labeled with anti-TLR2 mAb (PE-T2.5) or anti-TLR4 mAb (Alexa Fluor ${ }^{\circledR} 488-$ antimouse CD284) and examined by flow cytometry. Data shown are mean fluorescence intensity (MFI). (D) Murine peritoneal macrophages were pretreated with $1 \mu \mathrm{g} / \mathrm{ml}$ MALs, $1 \mu \mathrm{g} / \mathrm{ml}$ ELs or SC for the indicated times. Isolated RNA was reverse transcribed, and qRT-PCR was performed to determine TLR2 or TLR4 relative mRNA expression. The mean $\pm \mathrm{SD}$ (in relative units) of TLR 2 or TLR4 mRNA expression from three independent experiments is shown. SC, solvent control (0.005\% DMSO).

tolerance, in the control of mycobacterial infections compared to the control of infections by extracellular bacteria.

Because the NF- $\mathrm{KB}$ signaling pathway plays a critical role in the production of proinflammatory cytokines and $\mathrm{NO}$, the hyporesponsiveness induced with MALs may be associated with decreased NF- $\kappa B$ activity. In the present study, RAW264.7 cells pretreated with low doses of MALs followed by stimulation with PPD or heat-inactivated M. bovis BCG showed decreased NF- $\kappa B$ activity, which indicates that inhibitory factors preventing NF- $\mathrm{KB}$ activation may be present. IRAK-1 is a signaling molecule present upstream of NF- $\kappa \mathrm{B}$, and the suppression of IRAK-1 activation can block the subsequent activation of NF- $\kappa B$. Several inhibitory proteins, including SOCS-1, Tollip, and IRAK-M, have been reported to prevent the activation of IRAK-1 $(33,34)$. Researchers have demonstrated that IRAK-M is upregulated significantly in MDP or CpG DNA-induced tolerance and that inhibiting IRAK-M expression using siRNA restores reactivity to MDP in human primary monocyte-derived macrophages. In case of $\mathrm{CpG}$ DNA-induced tolerance, IRAK-M is significantly upregulated by real-time PCR, thereby implicating it in the mechanism of tolerance induction $(23,25)$. Consistent with the literature, we observed an upregulation of IRAK-M expression in murine peritoneal macrophages or RAW264.7 cells pretreated with a low dose of MALs for $48 \mathrm{~h}$. In addition, IRAK-M mRNA expression was increased following treatment with
MALs. These results suggest that the hyporesponsiveness of MAL-treated macrophages to stimulation with PPD or heat-inactivated M. bovis BCG is associated with a decrease in NF- $\mathrm{\kappa B}$ activation resulting from an increase in IRAK-M expression.

Because macrophages mainly sense mycobacterial components through pattern recognition receptors such as TLR2 and TLR4, we examined whether these receptors are involved in the mechanism of attenuated activation by MALs (22). We proved that the response of macrophages to PPD or heatinactivated M. bovis BCG is TLR2-dependent. Wang et al have demonstrated that lipoprotein Pam3Cys exposure led to the downregulation of TLR2 and, thus, to tolerance to a secondary stimulation (35). In the present study, however, we observed the dynamic expression of TLR2 after stimulation with $1 \mu \mathrm{g} / \mathrm{ml}$ MALs (Fig. 8D). These data, show that TLR2 expression was increased and maintained at a stable level up to $12 \mathrm{~h}$ post-stimulation. TLR2 levels then decreased in expression and remained low for 24-48 h after MALs stimulation. Taken together with the results in Fig. 4, we conclude that $1 \mu \mathrm{g} / \mathrm{ml}$ MALs can induce the expression of TLR2 but does not provoke cytokine production, despite the higher expression of TLR2. Moreover, TLR2 expression induced by PPD or heat-inactivated M. bovis BCG was not altered or attenuated by pretreatment with $1 \mu \mathrm{g} / \mathrm{ml}$ MALs. These results indicate that pretreatment with MALs attenuated the response 
of macrophages to MTB components through a mechanism independent of TLR2 and TLR4 expression.

In conclusion, we demonstrate that exposure to low-dose MALs can induce attenuated proinflammatory responses to MTB components and weaken the clearance of intracellular $M$. bovis BCG by murine macrophages. The attenuated responses induced by pretreatment with MALs are associated with decreased NF- $\kappa \mathrm{B}$ activity and increased IRAK-M expression.

\section{Acknowledgements}

We thank Yanjun Liu, Beiyi Liu, Sha Wu, Xiao Lu and Liyan Li for their kind advice on design and technique assistance. We also thank Mei Xu for the handling of experimental animals. The study was partly supported by the National Natural Science Foundation of China 30671970 to N.F.

\section{References}

1. Smith D, Wiegeshaus E and Balasubramanian V: An analysis of some hypotheses related to the Chingelput bacille CalmetteGuerin trial. Clin Infect Dis 31 (Suppl 3): S77-S80, 2000.

2. de Lisle GW, Wards BJ, Buddle B, M and Collins DM: The efficacy of live tuberculosis vaccines after presensitization with Mycobacterium avium. Tuberculosis (Edinb) 85: 73-79, 2005.

3. Flaherty DK, Vesosky B, Beamer GL, Stromberg P and Turner J: Exposure to Mycobacterium avium can modulate established immunity against Mycobacterium tuberculosis infection generated by Mycobacterium bovis BCG vaccination. J Leukoc Biol 80: 1262-1271, 2006.

4. Young SL, Slobbe L, Wilson R, Buddle BM, de Lisle GW and Buchan GS: Environmental strains of Mycobacterium avium interfere with immune responses associated with Mycobacterium bovis BCG vaccination. Infect Immun 75: 2833-2840, 2007.

5. Fine PE: The BCG story: lessons from the past and implications for the future. Rev Infect Dis 11 (Suppl 2): S353-S359, 1989.

6. Zhong J, Gilbertson B and Cheers C: Apoptosis of CD4 ${ }^{+}$and $\mathrm{CD}^{+} \mathrm{T}$ cells during experimental infection with Mycobacterium avium is controlled by Fas/FasL and Bcl-2-sensitive pathways, respectively. Immunol Cell Biol 81: 480-486, 2003.

7. Roger PM and Bermudez LE: Infection of mice with Mycobacterium avium primes $\mathrm{CD}^{+}$lymphocytes for apoptosis upon exposure to macrophages. Clin Immunol 99: 378-386, 2001.

8. Balcewicz-Sablinska MK, Gan H and Remold HG: Interleukin 10 produced by macrophages inoculated with Mycobacterium avium attenuates mycobacteria-induced apoptosis by reduction of TNF- $\alpha$ activity. J Infect Dis 180: 1230-1237, 1999.

9. Silva RA, Pais TF and Appelberg R: Blocking the receptor for IL-10 improves antimycobacterial chemotherapy and vaccination. J Immunol 167: 1535-1541, 2001.

10. Wagner D, Sangari FJ, Kim S, Petrofsky M and Bermudez LE: Mycobacterium avium infection of macrophages results in progressive suppression of interleukin-12 production in vitro and in vivo. J Leukoc Biol 71: 80-88, 2002.

11. Sangari FJ, Petrofsky $M$ and Bermudez LE: Mycobacterium avium infection of epithelial cells results in inhibition or delay in the release of interleukin-8 and RANTES. Infect Immun 67: 5069-5075, 1999.

12. Russell DG: Mycobacterium tuberculosis: here today, and here tomorrow. Nat Rev Mol Cell Biol 2: 569-577, 2001.

13. Sweet L, Singh PP, Azad AK, Rajaram MV, Schlesinger LS and Schorey JS: Mannose receptor-dependent delay in phagosome maturation by Mycobacterium avium glycopeptidolipids. Infect Immun 78: 518-526, 2010.

14. Horgen L, Barrow EL, Barrow WW and Rastogi N: Exposure of human peripheral blood mononuclear cells to total lipids and serovar-specific glycopeptidolipids from Mycobacterium avium serovars 4 and 8 results in inhibition of TH1-type responses. Microb Pathog 29: 9-16, 2000.

15. Shui W, Gilmore SA, Sheu L, Liu J, Keasling JD and Bertozzi CR: Quantitative proteomic profiling of host-pathogen interactions: the macrophage response to Mycobacterium tuberculosis lipids. J Proteome Res 8: 282-289, 2009.
16. Van Rhijn I, Nguyen TK, Michel A, Cooper D, Govaerts M, Cheng TY, van Eden W, Moody DB, Coetzer JA, Rutten V and Koets AP: Low cross-reactivity of T-cell responses against lipids from Mycobacterium bovis and M. avium paratuberculosis during natural infection. Eur J Immunol 39: 3031-3041, 2009.

17. Folch J, Lees M and Sloane SG: A simple method for the isolation and purification of total lipids from animal tissues. J Biol Chem 226: 497-509, 1957.

18. Zhang X, Goncalves R and Mosser DM: The isolation and characterization of murine macrophages. Curr Protoc Immunol 83: 14.1.1-14.1.14, 2008.

19. Fortier AH, Hoover DL and Nacy CA: Intracellular replication of Leishmania tropica in mouse peritoneal macrophages: amastigote infection of resident cells and inflammatory exudate macrophages. Infect Immun 38: 1304-1308, 1982.

20. Vavricka SR, Musch MW, Chang JE, Nakagawa Y, Phanvijhitsiri K, Waypa TS, Merlin D, Schneewind $O$ and Chang EB: hPepT1 transports muramyl dipeptide, activating NF- $\kappa$ B and stimulating IL-8 secretion in human colonic Caco2/bbe cells. Gastroenterology 127: 1401-1409, 2004.

21. Bekker LG, Moreira AL, Bergtold A, Freeman S, Ryffel B and Kaplan G: Immunopathologic effects of tumor necrosis factor alpha in murine mycobacterial infection are dose dependent. Infect Immun 68: 6954-6961, 2000.

22. Jo EK, Yang CS, Choi $\mathrm{CH}$ and Harding CV: Intracellular signalling cascades regulating innate immune responses to Mycobacteria: branching out from Toll-like receptors. Cell Microbiol 9: 1087-1098, 2007.

23. Dalpke AH, Lehner MD, Hartung T and Heeg K: Differential effects of CpG-DNA in Toll-like receptor-2/-4/-9 tolerance and cross-tolerance. Immunology 116: 203-212, 2005.

24. Dillon S, Agrawal S, Banerjee K, Letterio J, Denning TL, Oswald-Richter K, Kasprowicz DJ, Kellar K, Pare J, van Dyke T, et al: Yeast zymosan, a stimulus for TLR2 and dectin-1, induces regulatory antigen-presenting cells and immunological tolerance. J Clin Invest 116: 916-928, 2006.

25. Hedl M, Li J, Cho JH and Abraham C: Chronic stimulation of Nod 2 mediates tolerance to bacterial products. Proc Natl Acad Sci USA 104: 19440-19445, 2007.

26. Murphey ED, Fang G and Sherwood ER: Pretreatment with the Gram-positive bacterial cell wall molecule peptidoglycan improves bacterial clearance and decreases inflammation and mortality in mice challenged with Staphylococcus aureus. Crit Care Med 36: 3067-3073, 2008.

27. Murphey ED, Fang G and Sherwood ER: Endotoxin pretreatment improves bacterial clearance and decreases mortality in mice challenged with Staphylococcus aureus. Shock 29: 512-518, 2008.

28. Murphey ED and Sherwood ER: Pretreatment with the Grampositive bacterial cell wall molecule peptidoglycan improves bacterial clearance and decreases inflammation and mortality in mice challenged with Pseudomonas aeruginosa. Microbes Infect 10: 1244-1250, 2008.

29. Chan J, Tanaka K, Carroll D, Flynn J and Bloom BR: Effects of nitric oxide synthase inhibitors on murine infection with Mycobacterium tuberculosis. Infect Immun 63: 736-740, 1995.

30. Flynn JL, Goldstein MM, Chan J, Triebold KJ, Pfeffer K, Lowenstein CJ, Schreiber R, Mak TW and Bloom BR: Tumor necrosis factor- $\alpha$ is required in the protective immune response against Mycobacterium tuberculosis in mice. Immunity 2: 561-572, 1995.

31. MacMicking J, Xie QW and Nathan C: Nitric oxide and macrophage function. Annu Rev Immunol 15: 323-350, 1997.

32. Ehlers S, Kutsch S, Benini J, Cooper A, Hahn C, Gerdes J, Orme I, Martin C and Rietschel ET: NOS2-derived nitric oxide regulates the size, quantity and quality of granuloma formation in Mycobacterium avium-infected mice without affecting bacterial loads. Immunology 98: 313-323, 1999.

33. Kobayashi K, Hernandez LD, Galan JE, Janeway CJ, Medzhitov R and Flavell RA: IRAK-M is a negative regulator of Toll-like receptor signaling. Cell 110: 191-202, 2002.

34. Burns K, Clatworthy J, Martin L, Martinon F, Plumpton C, Maschera B, Lewis A, Ray K, Tschopp J and Volpe F: Tollip, a new component of the IL-1RI pathway, links IRAK to the IL-1 receptor. Nat Cell Biol 2: 346-351, 2000.

35. Wang JH, Doyle M, Manning BJ, Di Wu Q, Blankson S and Redmond HP: Induction of bacterial lipoprotein tolerance is associated with suppression of toll-like receptor 2 expression. J Biol Chem 277: 36068-36075, 2002. 